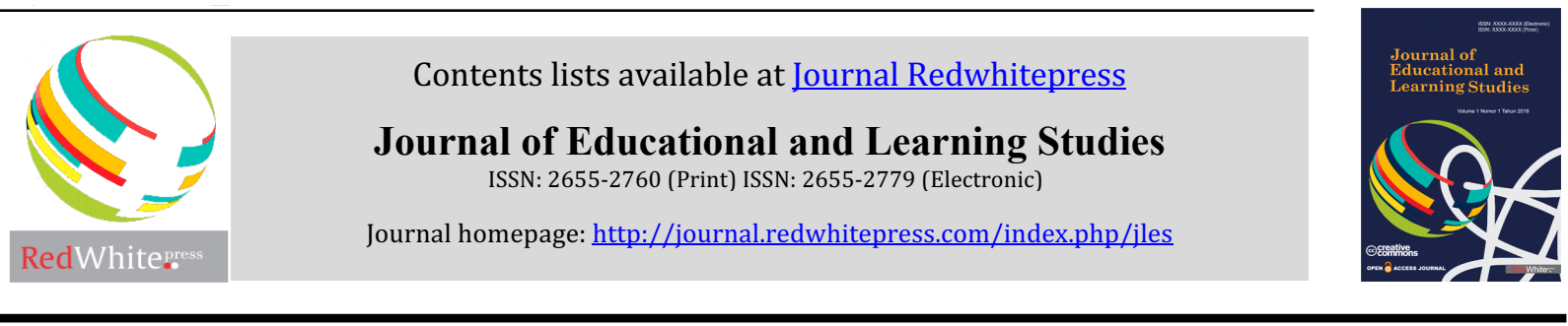

\title{
The Effectiveness of Cognitive Restructuring Techniques to Improve of Comprehension of Drug Abusers Among Student
}

\author{
Amri Love Lindra ${ }^{1}$, Yeni Karneli ${ }^{2}$, Marlina $^{3}$ \\ ${ }^{123}$ Universitas Negeri Padang
}

\begin{tabular}{l}
\hline \hline Article Info \\
\hline Article history: \\
Received Feb $19^{\text {th }}, 2020$ \\
Revised May $24^{\text {th }}, 2020$ \\
Accepted Jun $7^{\text {th }}, 2020$ \\
\hline
\end{tabular}

\section{Keyword:}

Group Guidance

Cognitive Restructuring to

Improve of Comprehension of

Drug Abusers Among Student

\begin{abstract}
Incorrect understanding of the dangers of drug abuse makes adolescents underestimate the dangers of drug abuse. Most drug users in adolescence, because adolescents have unstable and easily influenced characteristics and great curiosity. Drug use by adolescents in the early stages is trying to the stage of addiction. The purpose of this study is to look at the effectiveness of cognitive restructuring techniques in increasing understanding of the dangers of student drug abuse. This study uses in the form of a pseudo experimental design of The Non-Equivalent Control Group with pretest and posttest. The subjects of the study were students of class X TKR at SMK Muhammadiyah 1 Padang with a sample of 20 people divided into 2 groups consisting of 10 people as the experimental group and 10 people as the control group. The sampling technique with purposive sampling technique. Data were analyzed using Wilcoxon signed ranks test and Kolmogorov Smirnov two independent samples. The results of this study, concluded that cognitive restructuring techniques are effective in increasing understanding of the dangers of student drug abuse.
\end{abstract}

(C) 2020 The Authors. Published by Redwhitepress.

This is an open access article under the CC BY-NC-SA license

(https://creativecommons.org/licenses/by-nc-sa/4.0/

\section{Corresponding Author:}

Amri Love Lindra,

Universitas Negeri Padang

Email: lindraa156@yahoo.com

\section{Introduction}

Cognitive restructuring techniques can change behavior (Damayanti \& Nurjannah, 2016). Low understanding of the dangers of drug abuse causes teens to mis-respond to information about drugs and the dangers of abuse, because cognitive errors will produce wrong behavior. The fall of someone in drug abuse is caused by many factors, both internal and external. Internal factors consisting of unstable personalities, easily influenced, families that are less harmonious so that causes someone to feel hopeless and frustrated difficulty finding work is also one of the internal factors that cause people to want to become drug dealers, even people who have a good economy can also fall into drug abuse because of lack of attention and affection (Maudy \& Sahadi, 2017).

Drug abuse that hit the world becomes a scary thing for the Indonesian people, because drugs and psychotropic drugs have penetrated all regions of the country and in various circles. The target of drug trafficking is not only nightclubs, but has also spread to residential areas, campuses, boarding houses, schools, and even within the household (National Narcotics Agency, 2017). 
Drug abuse is a problem that afflicts people's lives, especially teenagers (Pertiwi, A., Karneli, Y., \& Afdal, A, 2019). Teenagers are the main target of the spread of drugs because the characteristics of adolescents are easily influenced. Adolescence is a very important period in the development of individual life. This period is often referred to as a transition period, namely the transition period from children to adults. At this time, the closeness between adolescents with parents and siblings began to decrease, no longer as in childhood, adolescents tend to be attracted to social life by making as many friends as possible. Teenagers spend more time with peers compared to family members (Suryani, 2014).

At this time every teenager tries to find identity that is marked by rebellious behavior towards the rules, authority, and dominance of parents and adults, unstable psychiatric conditions, easy to change attitudes and positions, as well as easily influenced and follow trends or fashions especially from peer groups, including lifestyle using drugs (National Narcotics Agency, 2004).

In accordance with the comprehensive curriculum in order to achieve the golden generation in 2045 and meet the educational goals in Indonesia, it is carried out in a technical setting with regard to calendar arrangement, rule selection and discipline (Daharnis \& Ardi, 2016). Implementation of rules and discipline in schools makes adolescents free from drug abuse. Nowadays there are many drug cases found in the young generation, ranging from the artist level, law enforcement, to the general public. Drug abuse in the world from year to year has increased (United Nations Office Drugs and Crime, 2015).

Increasing cases of drug abuse that are increasingly troubling must be addressed immediately, if no treatment is carried out it can cause many negative impacts and result in lost generation, because drug abuse has spread to all ages. Therefore, overcoming drug abuse becomes a shared responsibility starting from the family, school, community, and government (Darwis, 2017).

According to Beck (in karneli, 2019) changes in behavior and affection occur through changes in cognition. For this reason the interventions used must involve cognitive processes in order to change client behavior. Counseling paradigm which aims to help clients change behavior by focusing on cognitive abilities and client behavior. Improper understanding of adolescents about drugs is a cognitive aspect that causes teens to fall into drug abuse behavior. Lack of awareness in teenagers to learn because of ignorance of the benefits of learning or there is nothing you want to achieve (Marlina, 2017).

Cognitive restructuring techniques help adolescents to learn to think differently, to change wrong thoughts and replace them with more rational, realistic, and positive thinking (Tison, P., \& Hautekeete, M, 2007). Mistakes of thinking are expressed through negative self-statements (Hope, D. A., Burns, J. A., Hayes, S. A., Herbert, J. D., \& Warner, M. D, 2010). Negative self-statements indicate irrational thoughts, views and beliefs. Teenagers who experience unpleasant trauma, sad, scary, anxious and annoying, such as events: rape, war, family violence, accidents, natural disasters and certain events that make the mind depressed have an impact on emotional enhancement that will encourage individuals to consume alcohol, drug abuse, and suicide (Nirwana, 2016).

Adolescents will act preceded by thought processes so that changing non-adaptive behavior becomes adaptive (Reiss, D., \& Oliveri, M. E, 1980). The importance of cognitive improvement so that adolescents have a proper understanding of the dangers of drug abuse (Karneli et al., 2019). There is a significant relationship between understanding and drug abuse, research results prove that there is a positive relationship between students' understanding of drug abuse prevention measures. The higher students' understanding of drugs, the higher the prevention of drugs, it means students need to know how the relationship between drug abuse prevention measures and their knowledge of the dangers of drug abuse itself (Prisaria, 2012).

\section{Method}

This research is an experimental whose research design uses quasi experimental design The Non Equivalent Control Group Pretest and Posttest. The subjects in this study were students at SMK Muhammadiyah 1 Padang. The researchers chose this school as a place of research based on the consideration of smoking, in this case it was seen as an entry point for other more dangerous drug abuse, because cigarettes contain tobacco which has active substances that can cause dependencies such as nicotine, carbon monoxide and $\operatorname{tar}$ (Putri et al., 2013). To withdraw samples by using purposive sampling technique with a sample of 20 people. Samples taken in the medium and low categories were divided into two groups, namely 10 people as the experimental group and 10 people as the control group by taking students who have low and medium categories of comprehension. Data were analyzed using the Wilcoxon Signed Ranks test to measure the significance of the differences between two groups of data to see differences in the average score of students' understanding of the dangers of drug abuse before and after treatment. Whereas to see the difference in 
understanding after being given treatment between the experimental and control groups the Kolmogorov Smirnov test was used.

\section{Results and Discussions}

To be able to see differences in understanding the dangers of student drug abuse in the experimental and control groups by looking at the results of the pre-test and post-test. The control group experienced a significant change or increase after being provided with cognitive restructuring techniques. In the control group provided group guidance services on the topic of tasks about drug abuse also experienced a change but not significant. In the experimental group before being given treatment in the form of cognitive restructuring techniques the scores totaled 795 with an avarage of 79,5 in the low category. The following table is the result of experiments that have beeb carried out by researchers.

\begin{tabular}{ccllllll}
\hline & \multicolumn{2}{c}{ Pretest } & \multicolumn{2}{c}{ Posttest } & \multicolumn{2}{c}{ Score } & $\%$ \\
\cline { 2 - 5 } No & Score & Category & Score & Category & Difference \\
\hline 1 & 78 & Low & 81 & Medium & 3 & $4 \%$ \\
2 & 78 & Low & 98 & High & 20 & $26 \%$ \\
3 & 79 & Low & 101 & High & 22 & $28 \%$ \\
4 & 85 & Medium & 103 & High & 18 & $21 \%$ \\
5 & 79 & Low & 98 & High & 19 & $24 \%$ \\
6 & 85 & Medium & 107 & Very High & 22 & $26 \%$ \\
7 & 85 & Medium & 110 & Very High & 25 & $30 \%$ \\
8 & 86 & Medium & 94 & High & 8 & $10 \%$ \\
9 & 63 & Very Low & 84 & Medium & 21 & $33 \%$ \\
10 & 77 & Low & 102 & High & 25 & $32 \%$ \\
Amount & & 795 & & 978 & 183 & $23 \%$ \\
Average & 79,5 & Low & 97,8 & High & 18,3 & $23 \%$ \\
\hline
\end{tabular}

Furthermore, after being provided services using cognitive restructuring techniques the scores totaled 976 with an average of 97.6 and were in the high category. In the control group before being given guidance services the group score was 766 with an average of 76.6 in the low category, then after being given group guidance services with a task topic totaling 849 with an average of 84.9 in the medium category.

The difference in the frequency of the conditions of the experimental group and the control group from the results of the pretest and posttest about understanding the dangers of student drug abuse can be seen in the following table. In guidance and counseling there are many strategies used to assist students in overcoming problems related to the problem of lack of understanding about the dangers of drugs, one of the ways that can be done to improve students' understanding of the dangers of drugs (Prasetyo Rahayu, 2014). The findings in this study are that there are significant differences in the understanding of the dangers of drug abuse in the experimental group students and the control group. Furthermore, to better understand conceptually the results of the study, a discussion of the results of the study was conducted.

The results of the pretest study understanding the dangers of drug abuse of the experimental group students had 79.5 with an average of 7.95 and the control group had a number of 76.6 with an average of 7.66 indicating that both groups were equally in the low category. The division of the experimental group and the control group was done by looking at the results of the pretest scores for all group members and then divided based on the acquisition of pretest scores until the total score of the two groups was equal in category, this was done because the researcher wanted to see an increase in the understanding of the dangers of drug abuse of students at the posttest for the group experiment and control group.

Then the results of the pretest of the two groups were analyzed using the Kolmogorov Smirnov 2 Independent test obtained asymp.sig values. (2-tailed) of 0.164 or probability greater than 0.005 . From this it can be concluded that statistically, the pretest data of the experimental group and the control group did not have a significant difference or it could be said that the two groups were equal.

Based on the results of the study obtained an average pretest score of 79.5 with a low category, but scores on the posttest obtained 97.8 which is in the high category. The results of the study prove that cognitive restructuring techniques are more effective in increasing the understanding of the dangers of drug abuse for 
students. This can be seen from all group members experiencing an increase in the understanding of the dangers of drug abuse from the pretest and posttest results of the experimental group when the pretest is in the high category and at the posttest there was an increase in the category to high, and at the time of the pretest the two groups were both in the low category.

Based on data analysis, it is known that in the control group there are differences in the understanding of the dangers of drug abuse of students before being given group guidance services on the topic of assignment. Based on the acquisition of the pretest score obtained a value of 76.6 which is in the low category. After being given group guidance services on the topic of assignments there was a slight increase with a value of 84.9 in the medium category. Although statistically there are differences and an increase in the understanding of the dangers of drug abuse in control group students, but only increased in the moderate category.

Ireel (2018) suggests that one solution to overcome the high anxiety of students facing exams is to provide group counseling services with cognitive restructuring techniques, because it can utilize group dynamics as knowledge and cognitive exercises to restore positive, objective and rational thinking order can reduce student anxiety about examinations. In the implementation of this study aims to determine the effectiveness of cognitive restructuring techniques to improve understanding of the dangers of student drug abuse (Marlina, M \& Kusumastuti, G., 2019). The results showed that there were significant differences in the understanding of the dangers of drug abuse in the experimental group and control group students. Increased scores of experimental group students who experienced an increase in the understanding of the dangers of drug abuse by students were greater than those of the control group with the acquisition of an average score of 97.8 in the experimental group in the high category and an average score of the control group 84.9 that in the medium category.

Based on the results of the description above it can be seen that cognitive restrtrurization techniques are more effective in increasing the understanding of the dangers of student drug abuse. This effectiveness can be seen from the total number of analyzes conducted where the score of the results of understanding the dangers of drug abuse students in the experimental group increased compared to the control group. Thus the use of cognitive restructuring techniques can be applied on an ongoing basis in schools to increase students' understanding of the dangers of drug abuse in the context of alleviating and preventing drug abuse in schools.

\section{Conclusions}

The results obtained through this study, that understanding the dangers of student drug abuse can be improved by using cognitive restructuring techniques both classically and in groups. Analysis of research data explains that cognitive restructuring techniques are more effective in increasing understanding of the dangers of student drug abuse. Cognitive restructuring techniques under the guidance of group task topics both enhance understanding of the dangers of student drug abuse, but the scores for cognitive restructuring techniques are greater.

\section{References}

Daharnis, D., \& Ardi, Z. (2016). The compatibility student choice of university majoring; A preliminary studies. GUIDENA: Jurnal Ilmu Pendidikan, Psikologi, Bimbingan Dan Konseling, 6(1), 101-109.

Damayanti, R., \& Nurjannah, P. A. (2016). Pengaruh Konseling Kognitif Perilaku dengan Teknik Restrukturisasi Kognitif Terhadap Harga Diri Peserta Didik Kelas VIII Di MTs N 2 Bandar Lampung. KONSELI: Jurnal Bimbingan Dan Konseling (E-Journal), 3(2), 221-234.

Hope, D. A., Burns, J. A., Hayes, S. A., Herbert, J. D., \& Warner, M. D. (2010). Automatic thoughts and cognitive restructuring in cognitive behavioral group therapy for social anxiety disorder. Cognitive Therapy and Research, 34(1), 1-12.

Ireel, A. M., Elita, Y., \& Mishbahuddin, A. (2018). Efektivitas layanan konseling kelompok teknik restrukturisasi kognitif untuk mereduksi kecemasan menghadapi ujian siswa smp di kota bengkulu. Consilia: Jurnal Ilmiah Bimbingan Dan Konseling, 1(2), 1-10.

Karneli, Y., Ardimen, A., \& Netrawati, N. (2019). Keefektifan Konseling Modifikasi Kognitif Perilaku untuk Menurunkan Stres Akademik Siswa. JKI (Jurnal Konseling Indonesia), 4(2), 42-47.

Marlina, M. (2017). Increasing Self Regulated Learning Of Students with Special Needs through the Ilbawel Model. Journal of ICSAR, 1(1), 72-80.

Marlina, M., \& Kusumastuti, G. (2019). Social participation of students with special eucational needs in inclusive elementary schools. Specialusis Ugdymas, 1(39), 121-132. https://doi.org/10.21277/se.v1i39.412 
Nirwana, H. (2016). Konseling trauma pasca bencana. Ta'dib, 15(2).

Nurhusni, P. A. (2017). Profil penyesuaian sosial remaja yang mengalami kecanduan mengakses facebook. Indonesin Journal of Education Counseling, 1(2), 129-144.

PRASETYO RAHAYU, Y. (2014). Penerapan bimbingan kelompok dengan media video untuk meningkatkan pemahaman siswa tentang bahaya narkoba pada siswa kelas VIII-D SMP Negeri 2 Ngoro. Jurnal BK UNESA, 4(1).

Putri, R. M., Neviyarni, S., \& Daharnis, D. (2013). Pengembangan Modul Bimbingan dan Konseling untuk Pencegahan Penyalahgunaan Narkoba di Sekolah. Jurnal Konseling Dan Pendidikan, 1(2), 121-135.

Pertiwi, A., Karneli, Y., \& Afdal, A. (2019). Description of Adolescent Understanding at SMK Negeri 9 Padang on the Dangers of Drug Abuse. International Journal of Applied Counseling and Social Sciences, 1(1), 40-47.

Reiss, D., \& Oliveri, M. E. (1980). Family paradigm and family coping: A proposal for linking the family's intrinsic adaptive capacities to its responses to stress. Family Relations, 431-444.

Tison, P., \& Hautekeete, M. (2007). Effectiveness of cognitive restructuring on age-specific depressive cognitions. Behavioral and cognitive therapy journal , 17 (1), 25-32. 